\title{
Gender Relations in School Leadership in Albania
}

\author{
Teuta Çobaj \\ Director of Curriculum and Quality Inspection, State Inspectorate of Education \\ Email: tcobaj@gmail.com
}

\section{Doi:10.5901/ajis.2015.v4n2s2p109}

\begin{abstract}
This paper presents concerns of women's inequality in leadership as it is linked with the development of society and the role of women. Secondly, the paper examines the changes in attitudes towards teaching as a female profession based on published data from the Organization for Economic Cooperation and Development (OECD), which will later be used to discuss the evolution of the teaching profession in Albania as it stands in recent decades. The paper ultimately suggests that concepts of gender need to be revisited for future gender equality in education. In providing context with the above, the paper turns to asking about the representation of women in administrative roles in education. Do women posses a majority in school leadership? The paper provides a unique perspective into examining the weight of women in comparing women's roles as teachers in the education system versus the percentage of women in leadership roles in schools. Public perception and teachers' attitudes are positive as they pertain to the representation of women's leadership in schools. In conclusion, this paper discusses the risks posed in the gender imbalance in the number of teachers and school directors and how this, and similar models, create a trap of deformity in education. This paper does not only review the problems and causes of this phenomenon, but also provides concrete recommendations for an immediate intervention into the extensive teaching methods and strategies in Albania.
\end{abstract}

Keywords: gender equality, gender equity, gender justice, school leadership, gender relations in leadership.

\section{Introduction}

In Albania, women represent two-thirds of the total number of teachers, but they only make up a small percentage of leadership positions. The data is further denoted in the paper while also examining and valuing the position of women directly below leadership roles. The logical question that arises for each of us comes in connection with the causes of this situation. While the paper provides a review of the most significant causes, this is not meant to be an exhaustive discussion.

An important issue that arises from this discussion is tied into an outlook of the future from a gender perspective. What would a gendered perspective bring to the conversation and to the education system? In his "Why Don't More Men Go Into Teaching," New York Times reporter Motoko Rich predicted, "A change in the gender imbalance could sway the way teaching is regarded."

\section{Methodology}

This paper has employed secondary data from several national and international studies, especially that of the OECD. To complete the study with more quantitative methods, data has also been collected from 37 directors and education officers during February 2015. This data is from the State Inspectorate of Education (SIE). It provides information on the total number of teachers and principals, along with their gender affiliations. From this data, we can come to a conclusion about gender relations in education in the Department of Education and the Education offices throughout Albania.

The assessment of trends from perspectives towards gender in the teaching profession in Albania is also supplemented by annual quantitative data from the Ministry of Education and the Institute of Statistics (INSTAT). This paper has also taken into account qualitative data from:

a. A 183-question questionnaire completed by students majoring in Education with a concentration in Literature and Geography.

b. 45 interviews conducted with vice-principals from the Departments of Education in Tirana, Durrës, Korçë, and Vlorë during the period of February to January 2014. 


\section{Gender equality and equity}

"The major investments in the educational systems and the qualification of employees in the highest levels, can lead to the transformation of societies, specifically in agricultural areas towards the modernized and industrialized societies."

(2005 - "Integrimi gjinor ne arsim", botim I qendres "Aleance Gjinore per Zhvillim", p. 10)

Based on the published work "Gender Integration in Education" from the "Gender Alliance for Progress," in the 1960s and 1970s, there was a push towards equal progress for women based on theories similar to those on human capital. From annual improvements on social, health, and education standards, there would be a benefit of equality between men and women. This theory pushes towards the significance of an education system arguing that this advances societal standards. In the context of Albanian society the theory is especially important and necessary as we attempt to achieve the European perspective. These qualifications towards work provide high standards for both genders. guidelines:

In determining the concept of gender equality and equity, there is a foundational concept to understanding the

"Gender equality is referred to the unification or uniformity in quantity, quality and constancy of the applied programs for women and men. Usually equality must be seen from the legal framework." (2005 - "Integrimi gjinor ne arsim", botim I qendres "Aleance Gjinore per Zhvillim", p. 10)

While the term is defined as gendered justice, it is important to note the difficulty in defining and referring to this legislatively because equal gendered treatment can be fulfilled in a category of equality but not always in a category of justice.

"Gendered justice refers to all measures taken to secure equality for men and women" ("Integrimi gjinor në arsim", botim i qendrës "Aleanca Gjinore për Zhvillim", p. 10-11)

Unfortunately, we can provide examples of this from our experiences. During the period of dictatorship in the division of gender equality, women were at the front lines of the hardships along with men, without taking into consideration the physical differences between the two sexes.

In the famous "Ninety-Three," writer Victor Hugo writes in the last pages in the voices of two characters facing two worlds. One of the main changes sought after in the French Revolution of 1878 was gender equality. Through the voice of his characters, Hugo debated equality between the genders and the differences of this concept in the context of natural equality.

Concepts of gender justice and equality are necessary to discuss even in today's modern world, and naturally, in this ever changing world we will never be able to predict a legislation that will encompass all aspects of genders.

\section{Data from OECD for gender relations in education}

Changes and progress in the world have also influenced attitudes towards different genders against certain professions. The "Gender Integration in Education" states:

"Gender affiliations and identities refer to the female and male sexes, whereas attributes for women and men are created by society rather than biologically." ("Integrimi gjinor në arsim", botim i qendrës "Aleanca Gjinore për Zhvillim", p. 10-11)

Teaching does not fall under a biological role considering that not more than a few decades ago the profession was dominated by men.

According to data from the OECD: "In all levels of education, women make up two-thirds of teachers and academic staff, but the percentage of women as teachers decreases as the level of education and academia increases. For example, the average amount of women teachers according to the OECD is $97 \%$ in preschool, $82 \%$ in elementary school, less than 68\% in lower secondary education, and 56\% in higher secondary education." (Education at a Glance 2012 OECD, p. 68-69)

Why is there this global tendency for women to dominate in education? Or to phrase the question differently: "Why don't more men go into teaching?"

Motoko Rich, an education reporter for The New York Times, wrote in his September 6, 2014 article, "Why Don't More Men Go Into Teaching:" 


\begin{abstract}
"Jobs dominated by women pay less on average than those with higher proportions of men, and studies have shown that these careers tend to enjoy less prestige."
\end{abstract}

In the trade economy, Rich predicts that the laws of trade are once again functional in the way in which they are chosen and who chooses them. He puts into light the fact that an important reason for choosing a career can be tied to the income one receives from the profession. The average wage for a female teacher is roughly the same as the average wage for women in all professions, whereas the average wage for a male teacher is lower than the average wage for men in general. This paper will later discuss the causes around why women are dominating the teaching profession: more paid time-off and vacation, higher job security, higher benefits than other job positions, women are forced to work around their children's' schedules, etc.

\title{
5. What are the attitudes towards gender relations in teaching in Albanian education?
}

(Data from State Inspectorate of Education, taken from DAR/ZA-s on February 2015.)

The teaching profession has not been a profession dominated by women until recent decades. This paper refers to data and statics in order to examine the trends of recent decades. Data from the INSTAT during 1991-1999 reveals that the percentage of female teachers was $55 \%$ in 1991 (out of 28,789 teachers, 15,826 were women) and $63 \%$ in 1999 (out of 29,055 teachers, 18,129 were women). (Statistical yearbook 1991-1999 INSTAT, p. 152)

Statistical data from the Ministry of Education and Science (MASH) in the last decade reveals the continuing domination of women in teaching:

2004-2005 women constitute $66 \%$ of teachers

2005-2006 women constitute $68 \%$ of teachers

2006-2007 women constitute $69 \%$ of teachers

2007-2008 women constitute $70 \%$ of teachers

2008-2009 women constitute $71 \%$ of teachers

2009-2010 women constitute $71 \%$ of teachers

2010-2011 women constitute $72 \%$ of teachers

(Ministry of Education and Science, Statistical yearbook for education 2010-2011, p. 20)

These annual reports also reveal that $72 \%$ of people are in favor of women as teachers. In a need to refer to more detailed data for different periods of schooling, the same trends are revealed in the places of the OECD. The reports, on a cyclical basis, change in favor of men. In a nine-year (middle-school) education, the percentage of women teachers is at $75 \%$, whereas in high school women constitute $62 \%$ of teachers. In rural zones, this percentage increases once again in favor of men.

During the years of $2004-2011$, the percentage of women as teachers has increased by $6 \%$. The data that comes from teaching universities from recent years supplements this trend. More than $90 \%$ of students that study education are women, and in the second semester of a Master's program, the percent of women obtaining their Master's are again much higher compared to that of men. With this data in mind, this paper concludes that the trend of female teachers will continue in the coming years.

\section{Women and leadership in education}

When discussing general perceptions pertaining to gender relations in leadership in education, the immediate response is: This is not a problem, in our education system there is a large number of women principles. This is a perception that also arises from specialists in the field. In order to see whether or not this perception is accurate, this paper turns to statistics.

Based on the previously discussed data from OECD and in our country, the percentage of female teachers is above $70 \%$, but is this percentage similar when discussing women as principals and directors in our education system?

In nine-year schools, women constitute $75 \%$ of teachers, but only $43 \%$ of school principals, whereas men constitute $25 \%$ of teachers, but $58 \%$ of school principals. 


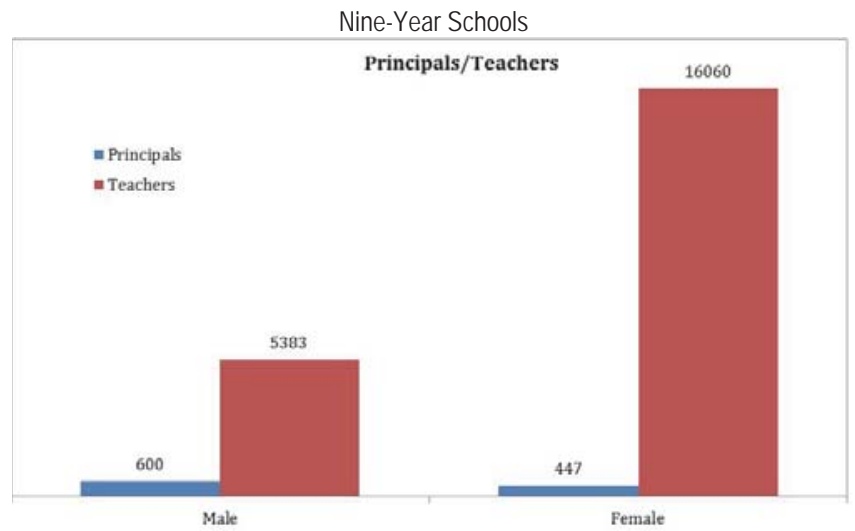

In referring to the data on numbers of vice-principals of schools compared to the number of principals, these would be the statistics: women constitute $68 \%$ of vice-principals while men comprise the other $32 \%$. From our interviews with school directors, the position of vice-principals is perceived as more convenient as it requires less hours, the wages are higher, and most importantly, according to the women in this position, they do not have direct responsibility.

High Schools

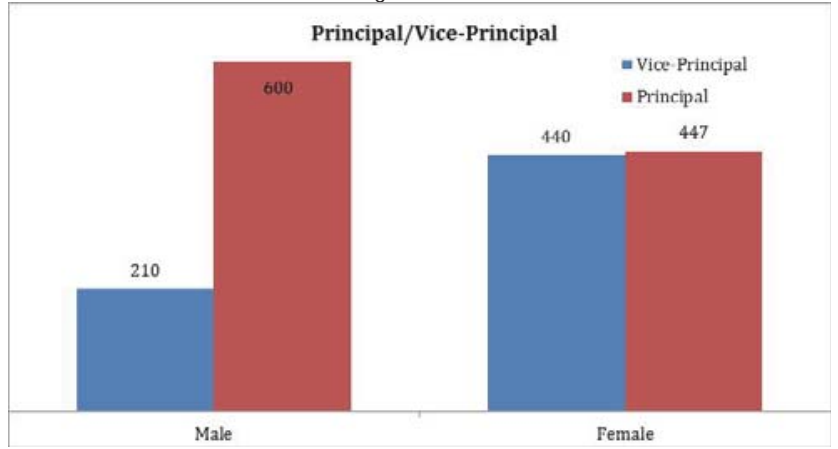

While female teachers constitute $62 \%$ of teachers in schools, they only make up $34 \%$ of the total number of directors in high schools. Even with an increase of the number of women in vice-principal positions at $51 \%$, that number is still low compared to the fact that women constitute $62 \%$ of teachers.

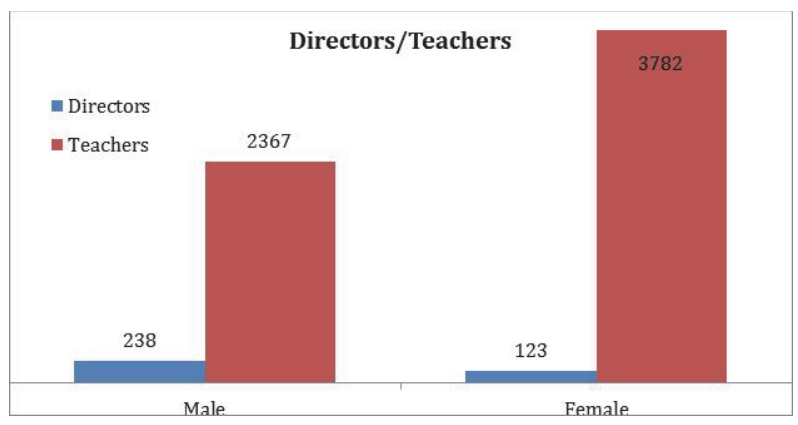

During the focus group, these are a series of reasons as to why women hesitated to accept a position as a principal:

The difficulty of the job, especially in high schools; the mentality that men are stronger physically and can better handle the job; long hours; chances of relocation, especially in rural areas; the existing mentality that gives men power 
over women in perceived power dynamics socially constructed in society, etc. What becomes most problematic is the fact that many of these comments arise from women themselves in stating that men are more suitable to accept these positions, especially those of high school principals. These women claim (almost unanimously in our focus group) that the vice-principal position with its shorter hours and a lack of direct-responsibility is more suitable than the principal position.

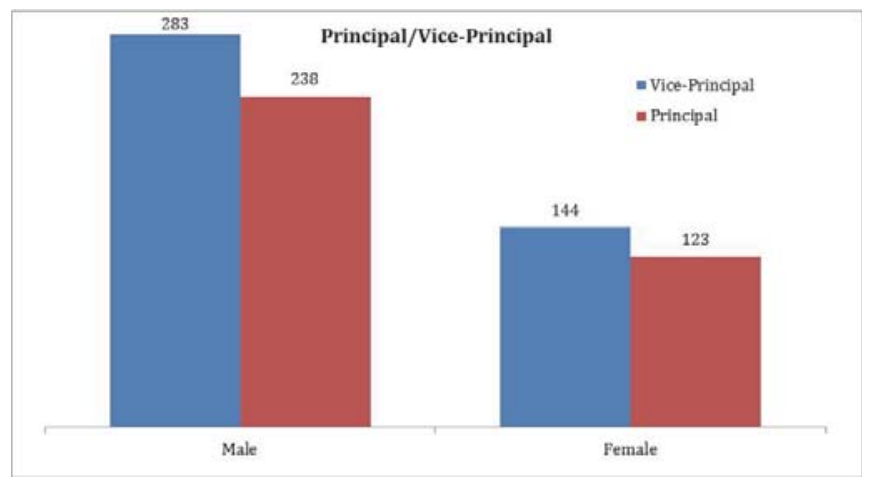

If we are to examine the data for rural zones, we can conclude that these percentages increase in leadership in favor of men. The example that is most shocking is that of DAR of Shkodër. From 13 directors in high schools, all 13 are men and none are women. The poor gender relations are seen in DAR in Durrës (5 female directors from 15 in all), DAR in Lezhë (3 female directors from 11 in all), ZA in Mat ( 0 female directors from 9 in all), DAR in Vlorë (5 female directors from 21 in all), DAR in Korçë (3 female directors from 17 in all). From this we can conclude that zones considered as urban have a higher tendency to place men as directors in schools.

\section{What has caused this trend?}

The concern towards a decreased role for women in leadership is tied with concerns in the progress of society and the role of women in this society. Even though women constitute a large portion of the work force, they do not constitute the same percentage in leadership.

Several theorists attribute this difference in their differing styles of leadership.

In the published work of PNUD, UN Women and the center for society and law, the center for children today, "Angazhimi i burrave dhe djemve kundër dhunës me bazë gjinore në Shqipëri" (p. 34) emphasizes:

"And even though it has been two decades of civil work and incentives in society to promote gender equality, gender equality still does not have the support it needs in Albania. The lack of belief in gender equality was seen as a precursor to the attitude towards violence, among other elements included in the study."

In a society where there are problems regarding gender equality, there is no doubt that this will be reflected in women in leadership.

Another factor tied to the notion that women cannot be institutional directors is linked with the constructed stereotype of the expectations of what it means to be a leader.

Often, the expectations in being a woman leader are:

"To behave exactly like their male partners, rather than to enrich their roles, and to bring new perspectives." (Shavlik \& Touchton, 1988, p. 101)

In their study titled "Gender and Leadership Style," Eagly and Jonson give importance to the context in which a leader functions:

"It is without a doubt that a style that is relatively democratic enriches the effectiveness of a leader in certain areas, and a style that is relatively autocratic enriches the leader in other areas."

According to Barbara B. Moran's study "Gender Differences in Leadership," which examines the perceived social 
quality of leaders as they pertain to both genders-a study that utilizes Hearn and Park's 1986-1987 "Woman, Man, and Leadership" (p. 38):

\begin{abstract}
'Leaders are often described with adjectives such as 'competitive,' 'aggressive,' or 'dominant,' which are typically associated with masculinity. A female leader is frequently regarded as an aberration and 'women who become leaders are often offered the presumed accolade of being described as being like men' (Hearn \& Parkin). For instance, Margaret Thatcher was often described as the "best man' in Great Britain." ("Gender differences in Leadership", Barbara B. Moran, p. 478)
\end{abstract}

Referring to Statham's (1987) study, Moran reiterates that women's style of leadership focuses on precision in the workplace and investing in others, whereas men focus their style more on investing in their own image and their autonomy. Even though there are different approaches towards this case of leadership, the experts in this field are of the same mindset that there is not one style, or one approach, that is better than the other. The success in a style of leadership is linked with a series of factors that need to be taken into consideration.

\title{
8. The gender inequality in the number of teachers and directors and the gender deformation trap
}

In the areas of the OECD, female teachers constitute $76 \%$ of all teachers, but the incorrect mainstream perception is that women are well represented and have a high percentage of leadership positions in the educational system. The notion that teaching is a female dominated profession seems as though it has been accepted globally, but what does this belief cause?

Motoko Rich in his article for The New York Times wrote:

"A change in the gender imbalance could sway the way teaching is regarded." (Motoko Rich, "Why Don't More Men Go Into Teaching").

Meanwhile, the impact of the model of a male leader in a similar context of education (with two-thirds women) has many possibilities.

In organizations, there is the same patriarchal family model where the leader is the male/husband. What becomes concerning is the fact that women themselves accept this model. In interviews with women in vice-principal positions, they state that it accommodates them more to be in this position as they have less direct responsibility. The hours of the position are also more and can allow for the women to have equilibrium in their roles as mothers and wives.

The National Strategy for Gender Equality and Domestic Violence (2007-2010) recommends: "The strengthening of the capabilities/capacities of educational institutions to integrate issues and concepts of gender equality in its planning, application, and monitoring in education."

In this same study, the recommendations are tied to improving educational programs: "To boost gender equality in improving the participation of women in teaching, planning, and managing education."

The situation is this: We have a model of female teaching that conveys the idea of gender equality and leader figure as being masculine dominated, similar to how children view family life and society.

According to the Gender Alliance for Progress's "Gender Perspectives in School Texts," special attention is paid to school texts and their role in creating a moral and legal conscious.

This study states:

"Texts, as sources of information, through examples, case-by-case situations, and didactic apparatus that target students, attempt to create on their own a part of moral and ethical consciousness that begins from a gender standpoint." (Aleanca Gjinore për Zhvillim 2008, "Prespektiva gjinore në tekstet shkollore”, p. 29)

While it is true that examples and situations contribute in the formation of students, interactions with others in society and life experiences are much more important and have a greater impact on students.

The model reflects again in parents and the community as the many contacts that are throughout schools.

"Leadership in society in general and in social institutions in particular is trusted more to male directors rather than female. Regarding results, we are taught to look specifically at male leaders, who govern in different aspects of spiritual and social life." ("Aleanca Gjinore për Zhvillim 2008, "Prespektiva gjinore në tekstet shkollore”, p. 29") 
The situation that is portrayed in the education system in the link between the inequality in the number of female teachers in the system compared to the number of female directors proves impactful in the creation of socially constructed stereotypes, which is why it is vital that policymakers hold a different viewpoint to avoid falling in this trap of gender distortion.

\section{Conclusion}

- The large investments made in the education system and training employees at higher levels can push towards transformations in societies, specifically in farming areas towards industrialization and modernization.

- The teaching profession does not fall under a biological role as not longer than a few decades ago men were the ones that dominated in the profession.

- According to the data from the OECD, in all levels of education women constitute two-thirds of teachers and academic staff. Men do not prefer education, as the average wages for education are lower than the average wages for men in the general job market.

- The percentage of female teachers for the $2014-2015$ academic year is at $72 \%$, whereas the percentage of female directors are only a small part of this overall number.

- The creation of these models in Albanian education creates a trap for gender distortion and deformation.

- A majority of experts link the disconnection between the two percentages between women in leadership and women in the workforce with women's difference in leadership styles.

- The main reasons for why men are positioned in roles as directors in schools are:

- The difficulty of the job, especially in high schools;

o The perceived stronger physique of men, which is viewed as allowing men to better withstand challenges;

- The longer hours of school principals;

- The chance of relocation, especially to rural zones.

- Another significant factor is the existing mentality that gives credit and encourages masculine tendencies in our society. What becomes difficult to understand is that women themselves accept these perceptions and mentality when it comes to the position of principal. The trend for women is to accept positions as vice-principals as this position provides better working hours and lacks direct responsibility. The inequality in the number of female teachers in the system and the number of female directors continues socially constructed gender stereotypes.

\section{Recommendations}

- The Department of Education must examine the situation created throughout schools and reassess in favour of establishing acceptable gender balances regarding the running of a school.

- In running schools, there needs to be a consistent percentage or affinity between men and women in the education system. This requires improvements and progression in policymaking that promote women in directing schools, which would be supported by a value system and not a part of positive discrimination policies aimed at them.

- It is imperative for the future to create methods and strategies that attract men to teaching in order to establish a gender balance.

- An increased awareness is necessary for women to accept more leadership roles. Women must be qualified and prepared for the workforce so as to recognize discrimination when it occurs and assist in preventing it.

- Women's organizations must assist in encouraging women towards making decisions to accept leadership positions by further educating and supporting these women.

- Female directors must be trained to assess the context in which they operate as leaders and to determine strategies that converge with their own style of leadership.

- There must be a minimization of causes that occur in stopping women from making decisions to become leaders as the emancipation of society from this aspect, until now, does not create a context that is conducive to this progress. The minimization of violence in society in this aspect is imperative. 


\section{References}

Aleanca Gjinore për Zhvillim, udhëzues "Integrimi gjinor në arsim".

Aleanca Gjinore për Zhvillim, 2008, "Perspektiva gjinore në tekstet shkollore", p. 17.

Barbara B. Moran, 1992, "Gender differences in Leadership", Library trends, vol 40, No.3.

Eagly \& Jonson , b. T. (1990), Gender and leadership style. Psikological Bulletin, p. 249.

ISHA, shkurt 2015, të dhëna të ardhura nga DAR/ZA-të e vendit.

OECD, 2012, Education at a Glance, p. 68-69.

Motoko Rich, 7 September 2014, "Why Don't More Men Go Into Teaching", on page SR3 of "The New York Time" edition. PNUD, UN Women dhe Qendra për Studime Sociale dhe Ligjore, Qendra Fëmijët Sot 2012.

"Fjalë Burri, angazhimi i burrave dhe djemve kundër dhunës me bazë gjinore në Shqipëri", p. 34.

Republika e Shqipërisë , INSTAT, vjetari statistikor 1991-1999, p. 152.

Shavlik \& Touchton, J.G. 1988, Women as leaders , p. 101.

Vjetari statistikor për arsimin 2010-2011. 